\title{
Zooplankton predators and preys: body size and stable isotope to investigate the pelagic food web in a deep lake (Lake Iseo, Northern Italy)
}

\author{
Barbara LEONI
}

Department of Earth and Environmental Sciences, University of Milano-Bicocca, Piazza della Scienza 1, 20126 Milan, Italy *Corresponding author: barbara.leoni@unimib.it

\section{ABSTRACT}

Seasonal changes in trophic position and food sources of deep subalpine lake (Lake Iseo, Northern Italy) zooplankton taxa were investigated during the year 2011. Furthermore, it is combined carbon and nitrogen Stable Isotope Analysis (SIA) with size-specific analyses of both, the major predatory cladoceran (Leptodora kindtii, Focke) and two potential preys (Daphnia longispina complex and Eub osmina longicornis). SIA studies have been extremely useful to track the energy flow through complex trophic network, however, if it is applied to analyze relation between two/few species may lead to misleading interpretations. In fact, integrating size-specificity allowed for understanding why L. kindtii nitrogen isotopic fingerprint fully overlapped with Daphnia, in spring. By investigating changes in L. kindtii's feeding basket, we found that in spring, L. kindtii mainly relied upon E. longicornis as prey, Daphnia being of too large body size for being captured by L. kindtii. Among preys encountered directly in front by a free-swimming Leptodora, only those able to fit into basket opening can be captured. As basket diameter increases with animal body length, size selection of prey depends on L. kindtii body length. As in other deep, subalpine lakes, E. longicornis was less ${ }^{15} \mathrm{~N}$-enriched than Daphnia, most likely because of exploiting nitrogen fixing, cyanobacteria colonies, commonly detected in Lake Iseo with the onset of thermal stratification. Cyclopoid adults were at the top of zooplankton food chain and they could potentially be feeding on Daphnia. They, however, likely fed in a different habitat (>20 m deep water), as suggested by a rather than negligible carbon fractionation. The results overall suggest that size-specificity is crucial for addressing space and time changes in trophic links between organisms composing the two hierarchical levels within open water zooplankton community.

Key words: Zooplankton; body size; trophic niche; stable isotope analyses; seasonality.

Received: April 2016. Accepted: September 2016.

\section{INTRODUCTION}

Ecological studies are increasingly devoted to quantifying functional roles of species through direct approaches, allowing for a better definition of food webs (Fink et al., 2012). As for aquatic environments, temporal and spatial changes in biological and physicochemical variables are relevant (Visconti and Manca, 2011). Zooplankton is a critical link in lake pelagic food webs: energy and matter accumulated through primary production and photosynthetic activity are early incorporated into primary consumers; and conveyed to planktivorous fish through zooplankton (primary and secondary consumers). Relative trophic position in pelagic food web of primary and secondary zooplankton consumers vary seasonally, thus affecting transfer of matter and energy, eventually pollutants, through the ecosystem (Bettinetti et al., 2012; Bettinetti and Manca, 2013). The entire process is regulated by size-specific interactions (Brooks and Dodson, 1965): size selectivity influencing grazing (Carpenter $e t$ al., 1985) of filter-feeding primary consumers, infra-zooplankton and fish predation (de Bernardi et al., 1987).

Quantifying taxa-specific trophic positions and how they vary seasonally is also an important step towards an evaluation of functional diversity, which is crucial for $e$.g. defining taxa vicariance and predicting impact of perturbations on ecosystem operational properties (e.g. Moss et al., 2009).

Among different approaches (e.g., gut contents, lipid biomarker analysis) for addressing seasonal changes in zooplankton trophic position and food sources, carbon and nitrogen Stable Isotope Analysis (SIA) is increasingly applied due to their ability to simultaneously summarize complex trophic networks and track the energy flow through them (Matthews and Mazumder, 2007 and references therein). The use of SIA has improved food-web descriptions due to their ability to simultaneously summarize complex trophic networks and track the energy flow through ecological communities. Organism carbon isotopic signatures are mainly related to habitat and lake typology and the ratio of $\delta^{13} \mathrm{C}$ changes only little as carbon flows through food-web (Smyntek et al., 2012; Rinta et al., 2015). In contrast, nitrogen isotopic signatures are strongly influenced by trophic position because the $\delta^{15} \mathrm{~N}$ of a consumer is typically enriched by $3-4 \%$ relative to its diet (Cattaneo et al., 2004; Perga and Gerdeaux, 2006; Visconti and Manca, 2011). Therefore, feeding histories of zooplankton taxa can 
be traced and quantified by comparing their carbon and nitrogen stable isotope signatures with those of potential food sources (Matthews and Mazumder, 2008; Wada, 2009).

In the present paper, I investigated the link between the seasonality of size structure of $L$. kindtii kindtii population and of two potential preys, along with isotopic variation in the plankton food web. It was expected to make inferences about seasonal changes in the trophic position of a range of zooplankton species. A deep subalpine lake, Lake Iseo, well-studied for both plankton and hydrochemistry (Salmaso et al., 2010, 2014; Leoni et al., 2014a, 2014b) offered a good opportunity for applying this approach and for comparing results with those obtained on other lakes in the region (i.e., Lake Maggiore, Manca et al., 2009; Visconti and Manca, 2011; Visconti et al., 2014). I hypothesized and tested: i) the diet shift of $L$. kindtii from feeding on small to large zooplankters depending on its seasonal size structure; ii) the space and time changes of few hierarchical levels within the zooplankton community.

\section{METHODS}

\section{Study site}

Lake Iseo (also known as Sebino) is the fourth largest Italian lake, after Garda, Maggiore and Como. It lies in the foothills of the Alps, at the end of a south alpine valley (Val Camonica). The inflow and outflow is the River Oglio, which forms the border between the provinces of Bergamo and Brescia. Like all subalpine lakes, Iseo has been classified by Hutchinson (1965) as 'warm monomictic', water temperatures do not drop below $4^{\circ} \mathrm{C}$ and water mixing occurring during or close to winter. Being deep, however, water overturn over the last 40 years has happened only occasionally (in 2005 and 2006, Pilotti et al., 2013; Leoni et al., 2014a), so the lake can presently be regarded as olooligomictic with anoxic conditions at the bottom in the deepest area (Garibaldi et al., 2003, Leoni et al., 2014a).

\section{Sample collection and laboratory analysis}

Zooplankton samples were collected seasonally in 2011 from a sampling station at the point of maximum

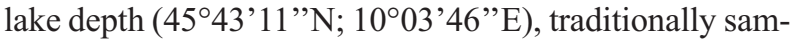
pled for long-term limnological studies (Fig. 1). Live zooplankton for isotopic analysis and body size was collected with large (58-cm opening mouth diameter), $450-\mu \mathrm{m}$ mesh nylon net through vertical hauls at $0-20 \mathrm{~m}$ depth (the water layer used for long-term lake monitoring; Leoni et al., 2014a). It was planned sampling in March, May, August and November to capture major seasonal changes in carbon and nitrogen zooplankton isotopic signatures (Visconti and Manca, 2011; Visconti et al., 2014) and in zooplankton population structure (Leoni et al., 2014a) and to estimate body size structure of zooplankton main preda- tors and potential preys.

Use of a large net mesh-size ensured that large phytoplankton colonies were avoided while allowing for capturing zooplankton components eligible as food for zooplanktivorous fish, which preferentially capture largebodied and well-visible zooplankters (de Bernardi et al., 1988). Water temperature vertical profiles were also measured on each sampling date with a multiprobe (WTW Multi 3410).

Organisms sorted by taxa were kept overnight in filtered (1.2 $\mu \mathrm{m} \mathrm{GF} / \mathrm{C}$ filters) lake water for gut clearance. Analyses included Daphnia longispina-galeata-cucullata complex (hereafter Daphnia), Eubosmina longicornis
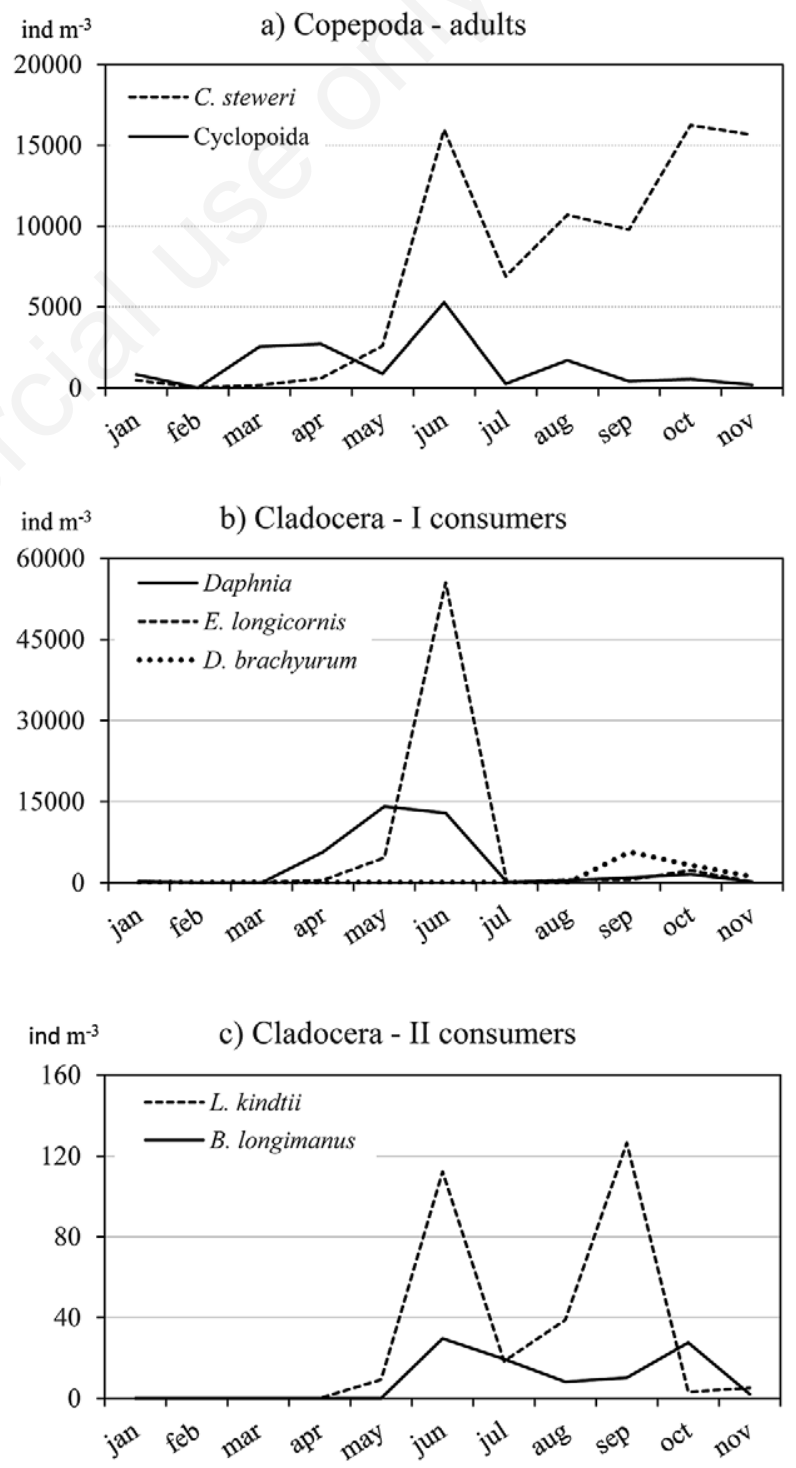

Fig. 1. Seasonal dynamics of zooplankton densities in Lake Iseo. a) Adults of Copepoda. b) Cladocera primary consumers. c) Cladocera secondary consumers. 
Schoedler 1866, Bythotrephes longimanus (Leydig 1860; Onychopoda) and Leptodora kindtii (Focke 1844; Haplopoda) among the Cladocera; Copidodiaptomus steueri, Brehm and Zederbauer, 1904, cyclopoids (Mesocyclops leuckarti Claus 1857 + Thermocyclops dybowskii Lande $1890+$ Cyclops abyssorum Sars 1863) among copepods. Early developmental stages of copepods and plankton rotifers were not included.

Depending on individual body mass, between 100 individuals/taxon (for B. longimanus) and 800 individuals/ taxon (for E. longicornis and the cyclopoids) were processed, to reach optimal weight requested per sample, two replicates of which were prepared. Fourteen zooplankton samples were analyzed for their $\delta^{13} \mathrm{C}$ and $\delta^{15} \mathrm{~N}$ isotopic signatures.

Samples were oven-dried at $60^{\circ} \mathrm{C}$ for $48 \mathrm{~h}$, finely powdered and then transferred into $5 \times 9 \mathrm{~mm}$ tin capsules (Manca et al., 1994). They were sent to the G.G. Hatch Stable Isotope Laboratory (University of Ottawa, Canada, www.isotope.uottawa.ca) where isotopic composition of organic carbon and nitrogen was determined by analysis of $\mathrm{CO}_{2}$ and $\mathrm{N}_{2}$ produced by combustion followed by gas chromatograph separation on a Vario EL III Elemental Analyser. Samples were sent into the DeltaPlus Advantage CF-IRMS via a ConFlo II interface. The analytical precision of the analyses (S.D.), based on the laboratory internal standards, was $<0.2 \%$ for both $\delta^{13} \mathrm{C}$ and $\delta^{15} \mathrm{~N}$.

Isotope ratios were expressed as parts per thousand (\%) differences from a standard reference (PeeDee Belemnite for carbon; atmospheric $\mathrm{N}_{2}$ for nitrogen), according to the following equation:

$\delta^{13} C, \delta^{15} N=\left[\left(R_{\text {sample }} / R_{\text {standard }}\right)-1\right] \times 1000$

where $\mathrm{R}$ is the isotopic ratio: ${ }^{13} \mathrm{C} /{ }^{12} \mathrm{C}$ and ${ }^{15} \mathrm{~N} /{ }^{14} \mathrm{~N}$.

Being conservative between consumer and food source, carbon isotopic ratios $\left(\delta^{13} \mathrm{C}\right)$ were used to assess the origin of carbon sources fuelling the pelagic food web and to detect seasonal changes in taxon-specific feeding behaviour. According to de Niro and Eipstein (1978), a common carbon source was attributed when fractionation $\left(F=\delta^{13} C_{\text {cons }}-\delta^{13} C_{\text {diet }}\right.$ ) was $\leq 0.8 \%$ ( $\pm 1.1 \%$ S.D. $)$. Nitrogen isotopic signatures $\left(\delta^{15} \mathrm{~N}\right)$, being enriched of $\approx 3.4 \% \pm$ $1.0 \%$ (Post, 2002) in consumers with respect to their direct diets (Enrichment, $E=\delta^{15} N_{\text {cons }}-\delta^{15} N_{\text {diet }}$ ), were used to assess seasonal changes in taxon-specific trophic positions. When a consumer carbon signature was related solely to the pelagic baseline, its trophic position $(T)$ was assessed by the simple linear equation:

\section{$T=(E / \lambda)+2$}

Where: $\lambda$ is the stepwise $E=3.4 \%$ (Matthews and Mazumder, 2003); and 2 is the value commonly assigned to the primary consumer used as isotopic baseline. Daphnia was used for tracing the pelagic baseline (Matthews and Mazumder, 2003; Marty and Planas, 2008), for its persistence in non-negligible abundance along the seasons and for its well-known ability of incorporating seston particles without taste selection (differently from e.g. copepods, Greene, 1988; Šorf and Brandl, 2012). At $T=3$, a consumer feeds directly on the primary consumer used as pelagic baseline; at $T=4$ an intermediate prey is between the two. At $T=2$ (and $F \leq 0.8 \pm 1.1$ ) the same trophic level as the baseline indicate that the zooplankter is an alternative prey to Daphnia for secondary consumers.

\section{Body size of zooplankton taxa}

Individual body length was estimated in each fixed sample, by using a PC image analysis software (AxioVision Rel. 4.6; Leoni and Garibaldi, 2009) connected with a microscope (Zeiss Axioskop 40, AxioCam MRc 5; 5x magnification eyepiece). Depending on population density, the number of analyzed individuals (representative of each population) varied between 100/sample (for Daphnia) and 40/sample (for E. longicornis). L. kindtii body length was measured from top of head to caudal portion of the body, furca excluded, on 251 individuals. Individual feeding basket diameter was estimated from Manca and Comoli (1995), to assess L. kindtii edible prey body length spectra along the seasons (Abrùsan, 2003).

Replicate samples, collected and fixed in buffered formaldehyde ( $4 \%$ by volume), were used for estimating zooplankton taxon abundance. Samples were collected by vertical tows from $20 \mathrm{~m}$ depth to the surface with a Wisconsin type net of $25 \mathrm{~cm}$ diameter and $200 \mu \mathrm{m}$ mesh, each sample was obtained by pooling three replicate hauls (3 hauls corresponding to $2.94 \mathrm{~m}^{3}$ of total filtered water). In the laboratory, Cladocera were identified and counted mostly to the species level. For details of procedures used in the field and laboratory see in Leoni et al. (2007).

\section{RESULTS}

\section{Seasonal changes in zooplankton population density}

In late Spring, Daphnia and E. longicornis reached their annual population density peaks. Diaphanosoma was found only in winter and autumn, in the latter season at its annual population density peak. The two predatory cladocerans, $L$. kindtii and B. longimanus, were found in springautumn and in summer-autumn, respectively (Fig. 1).

\section{Carbon and nitrogen isotopic signatures in the different seasons}

Daphnia carbon signature was least ${ }^{13} \mathrm{C}$-depleted in summer (-28.51\% $\pm 0.2 \mathrm{SD})$ and most ${ }^{13} \mathrm{C}$-depleted in win- 
ter $(-40.35 \% 0 \pm 0.2 \mathrm{SD})$, with intermediate and similar values in spring and autumn, $(-33.98 \% \pm 0.2 \mathrm{SD},-31.81 \%$ \pm 0.2 SD, respectively; Fig. 2). The seasonal pattern developed along with lake warming and progressive lake thermal vertical stratification, as observed in deep lakes (Perga and Gerdaux, 2006; Caroni et al., 2012).

Seasonal changes in carbon signatures of cladoceran taxa were consistent with those of Daphnia, suggesting exploitation of pelagic food sources. The cyclopoids relied upon pelagic food sources in winter, while being, later on, clearly more ${ }^{13} \mathrm{C}$-depleted $(-41.8 \pm 0.2 \mathrm{SD})$, than the other taxa, thus suggesting they might feed in deeper $(>20 \mathrm{~m}$ depth) waters, likely on preys other than those analyzed in this study (delta ${ }^{15} \mathrm{~N}$ of $9.0 \% \pm 0.2 \mathrm{SD}$; Fig. 3). Cyclopoids became progressively more ${ }^{15} \mathrm{~N}$-enriched towards summer $\left(10.04 \%{ }_{0} \pm 0.08 \mathrm{SD}\right.$, when they were at the same level as the predatory cladocerans $L$. kindtii $\left(9.09 \%{ }_{0} \pm 0.2 \mathrm{SD}\right)$ and B. longimanus $\left(10.14 \%{ }_{0} \pm 0.17 \mathrm{SD}\right)$, although by exploiting different preys.

In spring, E. longicornis fully overlapped with Daphnia for carbon isotopic signature (respectively $34.6 \pm 0.1$ $\mathrm{SD}$ and $-33.95 \pm 0.02 \mathrm{SD}$ ), while being nitrogen isotopic signature lower than Daphnia's (respectively $3.34 \pm 0.14$ S.D. and $5.76 \pm 0.8$ S.D.). At this time of year, Leptodora's carbon and nitrogen signatures overlapped with Daphnia $\left({ }^{13} \mathrm{C}:-33.32 \pm 0.06 \mathrm{SD}\right.$ and $-33.95 \pm 0.02 \mathrm{SD} ;{ }^{15} \mathrm{~N}: 5.76 \pm 0.8$ $\mathrm{SD}$ and $5.76 \pm 0.8 \mathrm{SD}$, respectively). Leptodora's enrich-

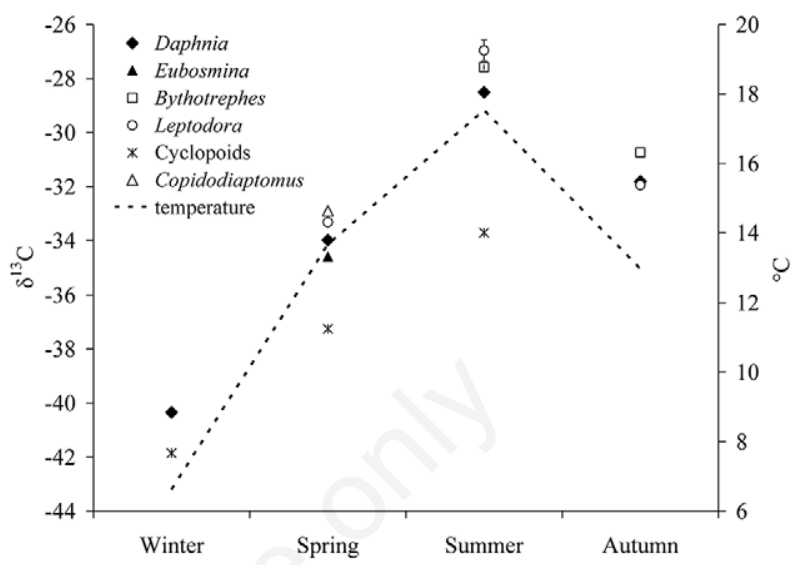

Fig. 2. Seasonal changes in carbon isotopic signatures of zooplankton taxa from Lake Iseo, 2011. Dotted line refers to water temperature (average) in the water layer from which zooplankton was sampled $(0-20 \mathrm{~m})$.
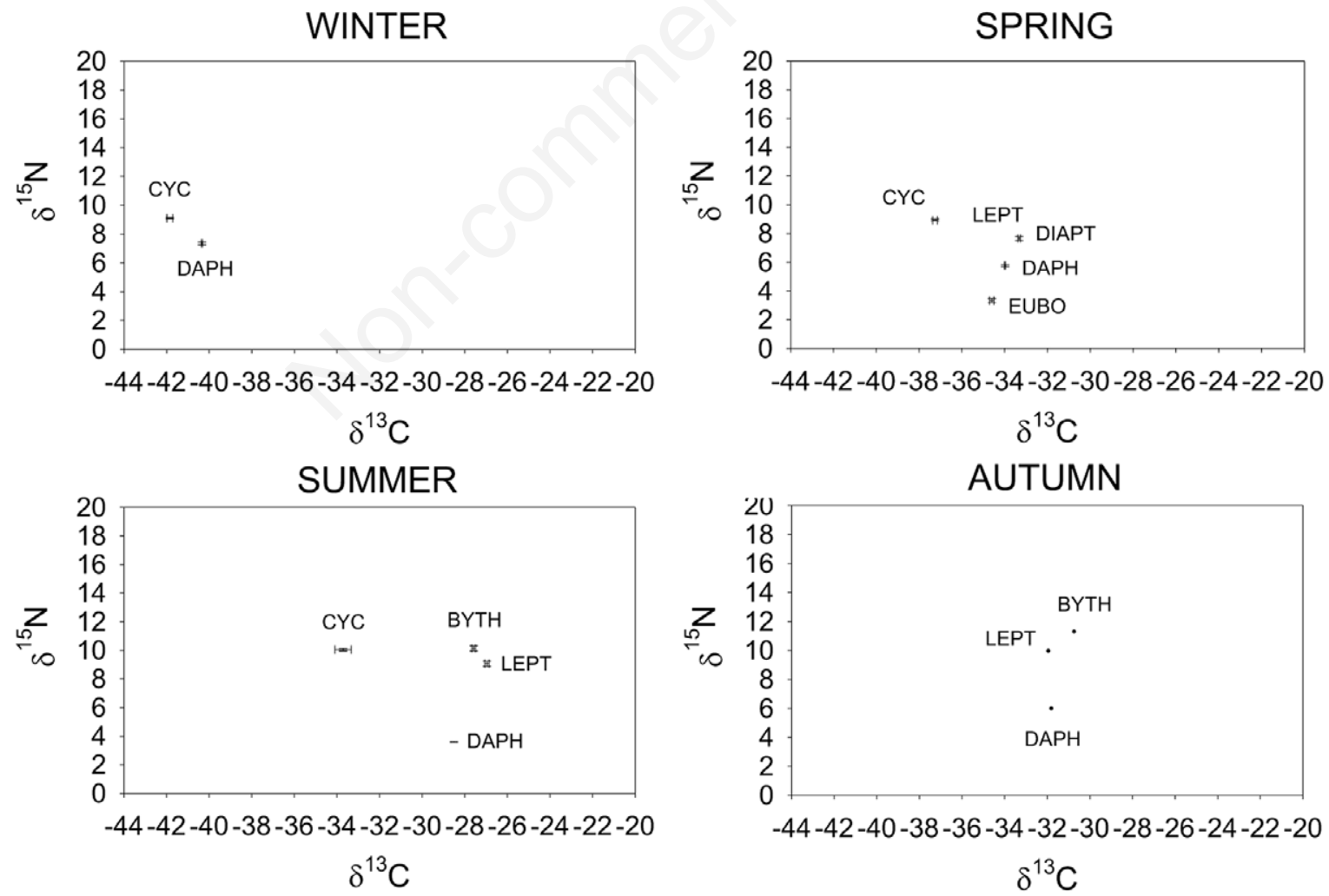

Fig. 3. Trophochemical graphs showing seasonal carbon and nitrogen isotopic signatures (average \pm SD) of zooplankton taxa from Lake Iseo, 2011. Byth, B. longimanus; Cyc, Ciclopoids; Diapt, Copidodiaptomus steweri; Dap, Daphnia longispina group; Eubo, E. longicornis; Lept, L. kindtii. In spring, L. kindtii and Copidodiaptomus steweri show similar signatures. 
ment was poor (0.3) and $T$ level low (2.6), both similar to those of Copidodiaptomus ( $E=0.5$ ).

In summer, $B$. longimanus shared carbon signature with L. kindtii, with respect to which, however, was more ${ }^{15} \mathrm{~N}$ enriched ( $E=6.5$ with respect to 5.5 ; Fig. 3 ). At this time of the year, however, Leptodora's carbon fractionation $(F=1.6)$, might suggest contribution of other than solely pelagic food sources exploited by $B$. longimanus. Also in autumn, $B$. longimanus increased carbon fractionation with respect to $L$. kindtii also suggests exploitation of different sources than those exploited by L. kindtii, the latter being more tightly linked to Daphnia carbon isotopic baseline.

Seasonal changes in L. kindtii feeding basket diameter (Fig. 4) suggest that the largest part of E. longicornis, and only a small fraction of Daphnia population, were eligible prey for L. kindtii in spring. In summer, L. kindtii basket range of sizes included $E$. longicornis, the latter being on average larger than in spring, along with a large fraction of Daphnia population (of body size between 0.6 and 1.2 $\mathrm{mm})$. In autumn, the entire range of E. longicornis body size and a fraction between 0.7 and $1.3 \mathrm{~mm}$ of Daphnia population were eligible prey, according to Leptodora's feeding basket size range. Overall, the results suggest that L. kindtii was able to prey on a large part of E. longicornis population, only marginally on Daphnia, the latter being mostly of body length exceeding the upper limit of $L$. kindtii basket diameter.

\section{DISCUSSION}

Carbon and nitrogen stable isotope analyses are increasingly used to trace conveyance of carbon sources

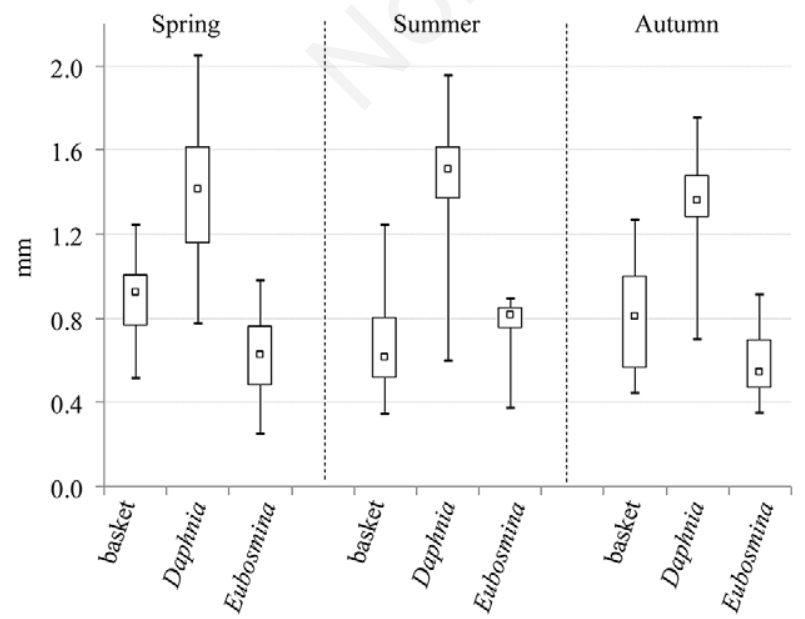

Fig. 4. Box-Whisker plots (boxes: median, upper and lower quartile; whiskers: minimum and maximum value) of seasonal changes in L. kindtii feeding basket (diameter) and body size (length) of potential cladoceran prey. through lake food webs and identifying zooplankton taxa roles and relationships (Matthews and Mazumder, 2005, 2006; Persaud et al., 2012). A major concern is that I cannot address prey available for a given predator, as I do not actually know all actors in the scene of the lake theatre, nor I know all possible roles they might play (Hutchinson 1965). Yet, stable isotopes analyses revealed unexpected trophic links in food web structure, also related to predator and prey body sizes (Matthews and Mazumder, 2007; Kuwae et al., 2012).

Size-specificity is a major trait governing biotic and abiotic interactions within and between the zooplankton (Geller and Müller 1981; Peters, 1983; Porter et al., 1983, Obertegger and Manca, 2011). Size-specificity in prey selection characterizes the predatory cladoceran L. kindtii. This carnivorous cladoceran swims continuously through the water column ('cruise predator'; Greene, 1988), capturing prey by means of five pairs of thoracic appendages spread to form a feeding basket (Herzig and Auer, 1990; Manca and Comoli, 1995; Vogt et al., 2013). Among preys encountered directly in front by a free-swimming L. kindtii, only those able to fit into basket opening can be captured. As basket diameter increases with animal body length, size selection of prey depends on Leptodora's body length.

In this study, Daphnia has been used as pelagic baseline, as a short-lived organism, it is better suited for finer scale temporal integration of pelagic $\mathrm{d} 13 \mathrm{C}$ or $\mathrm{d} 15 \mathrm{~N}$ signatures; furthermore, due to its unselective mode to feeding it constitutes a good estimate for base of the food chain (Matthews and Mazumder, 2003). It has been found that L. kindtii overlapped with Daphnia in Spring, not only for carbon, which is indicative of common sources, but also for nitrogen isotopic signature. The lack of enrichment with respect to Daphnia suggested that L. kindtii did not prey on Daphnia during Spring. Analysis of $L$. kindtii feeding basket size suggested that one possible alternative prey, namely E. longicornis, well fitted Leptodora's size-specific predation in Spring. A close predator-prey seasonal dynamics between $L$. kindtii and E. longicornis were found in other deep, large lakes (e.g., Lake Michigan, Branstrator and Lehman, 1991). I cannot, however, exclude contribution by other preys to Leptodora's predation, such as Conochilus sp., Rotifera (Edmondson and Litt, 1987). The latter, however, were not among the major components of zooplankton in Lake Iseo, only occasionally being found in high densities (e.g., in June 1999, July 2003-2005; Garibaldi et al., 2003; Leoni et al. 2014a).

Rotifera were not included in this study focused on size fraction of crustacean zooplankton potentially exploited by planktivorous fish of Lake Iseo, such as Leuciscus cephalus, L. souffia, Alosa fallax lacustris and Coregone lavaretus (de Bernardi et al., 1988). 
Unique interpretations cannot be achieved, particularly when I face complexity of the natural environment. On the other side, extrapolation from the laboratory to the field is complicated by the temporal and spatial heterogeneity of the natural environment (Kareiva et al., 1996), particularly because short generation times allow zooplankton to respond rapidly to changing abiotic conditions or biotic interactions (Adrian et al., 2006). Stable isotopes analyses have, with respect to e.g., laboratory feeding experiments, the potential of combining field and laboratory approaches, tracing at fine, molecular level (Strayer, 2010) time-specific, step-wise functional role of organisms in the ecosystem.

In spring, when the pelagic food web was most diversified, Daphnia was not the less ${ }^{15} \mathrm{~N}$-enriched open-water zooplankter. In fact, E. longicornis showed a lowest nitrogen isotopic signature; this trait is common of deep lakes in the subalpine region (Visconti et al., 2014). When Daphnia and E. longicornis carbon signatures overlap, thus suggesting habitat sharing (Visconti et al., ibidem), differences in nitrogen isotopic signatures can be reasonably explained by taking into account the feeding behaviour. Food particles are retained by Daphnia through filter combs bared by thoracic limbs, in a range of sizes constrained by the distance between the setae forming the combs (Geller and Müller, 1981). Such distance tends to increase with body size (Geller and Müller, 1981), thus allowing larger species/specimens for retaining increasingly larger food particles, and smaller ones, to exploit also small food particles, such as bacteria. Using Daphnia as tracer, seasonal changes in size of seston particles fuelling pelagic food web are accounted for E. longicornis feeding behaviour is quite different from Daphnia's (DeMott and Kerfoot, 1982). E. longicornis is able to feed on filamentous colonies, including those of Cyanobacteria. Cyanobacteria are usually lower in nitrogen isotopic signature than other phytoplankton taxa; nitrogen-fixing cyanobacteria in particular, are poor in heavy isotope, being almost un-enriched with respect to standard samples (Carpenter et al., 1999). Ability to exploit also poorly ${ }^{15} \mathrm{~N}$ enriched food sources is a reasonable explanation for $E$ bosmina's low nitrogen isotopic signature. A predator will be relatively less enriched when selecting E. longicornis than Daphnia as prey, enrichment being related to predator's body size. Such was the case for L. kindtii in Lake Iseo in spring, as E. longicornis fells within size range of Leptodora's potential prey (Fig. 4).

As commonly observed in deep subalpine lakes, pelagic baseline signatures were, respectively, least ${ }^{13} \mathrm{C}$ depleted and ${ }^{15} \mathrm{~N}$-enriched in summer.

Carbon isotopic signature is affected by water depth (Zohary et al., 1994; Gu et al., 1996; Lehmann et al., 2004; Manca et al., 2009; Visconti and Manca, 2011). In the epilimnion of deep lakes, $\delta^{13} \mathrm{C}$ signature increases with warm- ing and onset of thermal stratification (Perga and Gerdeaux, 2006; Manca et al., 2009; Visconti and Manca, 2011; Caroni et al., 2012). Temperature controls the solubility of $\mathrm{CO}_{2}$ and in turn influences the fractionation of carbon isotopes during phytoplankton uptake (Rau et al., 1989, 1992; Grey et al., 2001). Particularly in late spring and summer, carbon baseline signature reflects contribution by phytoplankton (Pel et al., 2003; Matthews and Mazumder, 2005; Perga and Gerdeaux, 2006). Changes in phytoplankton community structure and functional groups are also related to carbon isotopic signature (Caroni et al., 2012).

A decrease in nitrogen baseline isotopic signature in spring and summer is common for deep lakes: it is attributed to recycling by the zooplankton in the epilimnion. In spring, the rapid increase in primary consumers led to excretion of $\mathrm{N} / \mathrm{NH}_{4}$, depleted in heavy isotope (Peterson and Fry, 1987) and quickly assimilated by primary producers. Moreover, different algal groups along the seasons contributing to phytoplankton biomass also differ in nitrogen fractionation (Adams and Sterner, 2000; Lehman et al., 2004). Lake Iseo seasonally exhibits concentrations of cyanobacteria (mostly Planktothrix rubescens), green algae (mainly Sphaerocystis schroeteri), Conjugatophyceae (mostly Mougeotia spp.) and diatoms (mainly Fragilaria sp. and Diatoma elongatum) (Leoni et al., 2014a, 2014b; Marti et al., 2016).

As in Lake Maggiore, the most ${ }^{15} \mathrm{~N}$ enriched crustacean zooplankter in Lake Iseo was B. longimanus longimanus, in summer sharing the same $E$ as the cyclopoids. Thus, cyclopoid adults were at the top of zooplankton food chain and they could potentially be feeding on Daphnia. They, however, likely fed in a different habitat $(>20$ $m$ deep water), as suggested by a rather than negligible carbon fractionation. In Lake Iseo, B. longimanus' presence in the open-water was restricted to summer and autumn. The enrichment was close but slightly higher than Leptodora's, suggesting exploitation of intermediate preys in addition to Daphnia.

\section{CONCLUSIONS}

The novel aspect of this work is the combination of zooplankton body size structure and isotopic variation of carbon and nitrogen. It was analyzed the stable isotopic composition ( $\mathrm{C}$ and $\mathrm{N}$ ) of several cladocerans and copepods taxa of Lake Iseo, in four seasons. At the same time, it was measured the feeding basket size of predator and body size of potential prey to better investigate predatorprey interactions in zooplankton community. Combining seasonal changes in the size structure with carbon and nitrogen stable isotopes analyses of zooplankton taxa from a deep subalpine lake, I attempted to take into account size-specificity, an important trait governing seasonal changes in zooplankton population structure. 
It was found that the apparent anomaly of being an important invertebrate predator, Leptodora, almost un-enriched with respect to Daphnia, was reasonably consequent to ability to exploit alternative, other-thanDaphnia prey, e.g. Eubosmina, whose nitrogen signature was less ${ }^{15} \mathrm{~N}$-enriched than Daphnia's. The results overall suggest that size-specificity is crucial for addressing space and time changes in trophic links between organisms composing the two hierarchical levels within open water zooplankton community. This study, however, cautions against universal uncritical application of general rules of isotopic fractionation to all aquatic food webs. This research also underlines the need to extend stable isotope studies to components, which might have been overlooked, in view of a better understanding of roles zooplankton taxa may play in pelagic food web.

\section{ACKNOWLEDGMENTS}

I especially want to thank Dr. Stefano Beluzzi for his help during the field sampling and laboratory analyses. This study was made in the framework of the LTER (Long Term Ecological Research) Italian network, site "Southern Alpine lakes", IT08-000-A (http://www.lteritalia.it/).

\section{REFERENCES}

Abrùsan G, 2003. Morphological variation of the predatory cladoceran L. kindtii kindtii in relation to prey characteristics. Oecologia 134:278-283.

Adams TS, Sterner RW, 2000. The effect of dietary nitrogen content on trophic level ${ }^{15} \mathrm{~N}$ enrichment. Limnol. Oceanogr. 45:601-607.

Adrian R, Wilhelm S, Gerten D, 2006. Life-history traits of lake plankton species may govern their phenological response to climate warming. Glob. Change Biol. 12:652-661.

Bettinetti R, Garibaldi L, Leoni B, Quadroni S, Galassi S, 2012. Zooplankton as an early warning system of persistent organic pollutants contamination in a deep lake (Lake Iseo, Northern Italy). J. Limnol. 71:335-338.

Bettinetti R, Manca M, 2013. Understanding the role of zooplankton in transfer of pollutants through trophic food webs, p. 1-18. In: G. Kehayias (ed.), Zooplankton: species diversity, distribution and seasonal dynamics. Nova Science Publishers, Inc., Hauppauge.

Branstrator DK, Lehman JT, 1991. Invertebrate predation in Lake Michigan: Regulation of Bosmina longirostris by $L$. kindtii kindtii. Limnol. Oceanogr. 36:483-495.

Brooks JL, Dodson SI, 1965. Predation, body size and composition of plankton. Science 150:28-35.

Caroni R, Gary F, Visconti A, Manca M, 2012. Phytoplankton functional traits and seston stable isotopes signature: a functional-based approach in a deep, subalpine lake, Lake Maggiore (N. Italy). J. Limnol. 71:e8.

Carpenter SR, Kitchell JF, Hodgson JR, 1985. Cascading trophic interactions and lake productivity. BioScience 35:634-639.
Carpenter EJ, Montoya JP, Burns J, Mulholland MR, Subramaniam A, Capone DG, 1999. Extensive bloom of a N-fixing diatom/cyanobacterial association in the tropical Atlantic Ocean. Mar. Ecol. Prog. Ser. 185:273-283.

Cattaneo A, Manca M, Rasmussen JB, 2004. Peculiarities in the stable isotope composition of organisms from an alpine lake. Aquat. Sci. 66: 440-445.

de Bernardi R, Giussani G, Manca M, 1987. Cladocera: predators and prey. Hydrobiologia 145:225-243.

de Bernardi R, Giussani G, Manca M, 1988. Seasonal evolution of Cladocera in Lago Maggiore (N. Italy) as influenced by environmental parameters. Verh. Internat. Verein. Limnol. 23:530-534.

DeMott WR, Kerfoot WC, 1982. Competition among cladocerans: nature of the interaction between Bosmina and Daphnia. Ecology 63:1949-1966.

De Niro MJ, Epstein S, 1978. Influence of diet on the distribution of carbon isotopes in animals. Geochim. Cosmochim. Ac. 42:495-506.

Edmondson WT, Litt AH, 1987. Conochilus in Lake Washington. Hydrobiologia 147:157-162.

Fink P, Reichwaldt ES, Harrod C, Rossberg AG, 2012. Determining trophic niche width: an experimental test of the stable isotope approach. Oikos 121:1985-1994.

Garibaldi L, Anzani A, Marieni A, Leoni B, Mosello R, 2003. Studies on the phytoplankton of the deep subalpine Lake Iseo. J. Limnol. 62:177-189.

Geller W, Müller H, 1981. The filtration apparatus of Cladocera: filter mesh-sizes and their implications on food selectivity. Oecologia 49:316-321.

Greene CH, 1988. Foraging tactics and prey-selection patterns of omnivorous and carnivorous calanoid copepods. Hydrobiologia 167:295-302.

Grey J, Jones RI, Sleep D, 2001. Seasonal changes in the importance of the source of organic matter to the diet of zooplankton in Loch Ness, as indicated by stable isotope analysis. Limnol. Oceanogr. 46:505-513.

Gu B, Schelske CL, Hoyer MV, 1996. Stable isotope of carbon and nitrogen as indicators of diet and trophic structure of the fish community in a shallow hypereutrophic lake. J. Fish Biol. 49:1233-1243.

Herzig A, Auer B, 1990. The feeding behaviour of L. kindtii kindtii and its impact on the zooplankton community of Neusiedler See (Austria). Hydrobiologia 198:107-117.

Hutchinson GE, 1965. The ecological theatre and the evolutionary play. Yale University Press, New Haven: 139 pp.

Kareiva P, Parker MP, Pascual M, 1996. Can we use experiment and models in predicting the invasiveness of genetically engineered organisms? Ecology 77:1670-1675.

Kuwae T, Miyoshi E, Hosokawa S, Ichimi K, Hosoya J, Amano T, Moriya T, Kondoh M, Ydenberg RC, Elner RW, 2012. Variable and complex food web structures revealed by exploring missing trophic links between birds and biofilm. Ecol. Lett. 15:347-356.

Lehmann MF, Bernasconi SM, McKenzie JA, 2004. Seasonal variation of the $\delta^{13} \mathrm{C}$ and $\delta^{15} \mathrm{~N}$ of particulate and dissolved carbon and nitrogen in Lake Lugano: constraints on biogeochemical cycling in a eutrophic lake. Limnol. Oceanogr. 49:415-429.

Leoni B, Garibaldi L, 2009. Population dynamics of Chaoborus 
flavicans and Daphnia spp.: effects on a zooplankton community in a volcanic eutrophic lake with naturally high metal concentrations (L. Monticchio Grande, Southern Italy). J. Limnol. 68:37-45.

Leoni B, Garibaldi L, Gulati RD, 2014a. How does interannual trophic variability caused by vertical water mixing affect reproduction and population density of the Daphnia longispina group in Lake Iseo, a deep stratified lake in Italy? Inland Waters 4:193-203.

Leoni B, Marti C, Imberger J, Garibaldi L, 2014b. Summer spatial variations in phytoplankton composition and biomass in surface waters of a warm-temperate, deep and oligoholomictic lake: Lake Iseo, Italy. Inland Waters 4:303-310.

Leoni B, Morabito G, Rogora M, Pollastro D, Mosello R, Arisci S, Forasacco E, Garibaldi L, 2007. Response of planktonic communities to calcium hydroxide addition in a hardwater eutrophic lake: results from a mesocosm experiment. Limnology 8:121-130.

Manca M, Comoli P, 1995. Seasonal changes in size of the feeding basket of L. kindtii kindtii (Focke) in Lago Maggiore as related to variations in prey size selection. Limnol. Oceanogr. 40:834-838.

Manca M, Spagnuolo T, Comoli P, 1994. Variations in carbon and nitrogen content with body length of Daphnia hyalinagaleata s.l. from laboratory and field observations. J. Plankton Res. 16:1303-1314.

Manca M, Visconti A, Fadda A, Caroni R, Cerutti I, Volta P, 2009. [Indagini sullo zooplancton e sulla rete trofica pelagica attraverso analisi d'isotopi stabili di carbonio e azoto], p. 34-52. In: CNR-ISE (ed.), [Ricerche sull'evoluzione del Lago Maggiore. Aspetti limnologici. Programma quinquennale 2008-2012. Campagna 2008]. [Book in Italian]. Commissione Internazionale per la protezione delle acque italo-svizzere.

Marti CL, Imberger J, Garibaldi L, Leoni B, 2016. Using time scales to characterize phytoplankton assemblages in a deep subalpine lake during the thermal stratification period: Lake Iseo, Italy. Water Resour. Res. 52:1762-1780.

Marty J, Planas D, 2008. Comparison of methods to determine algal $\delta^{13} \mathrm{C}$ in freshwater. Limnol. Oceanogr.-Meth. 6:51-63.

Matthews B, Mazumder A, 2003. Compositional and interlake variability of zooplankton affect baseline stable isotope signature. Limnol. Oceanogr. 48:1977-1987.

Matthews B, Mazumder A, 2005. Temporal variation in body composition $(\mathrm{C}: \mathrm{N})$ helps explain seasonal patterns of zooplankton $\delta^{13} \mathrm{C}$. Freshwater Biol. 50:502-515.

Matthews B, Mazumder A, 2006. Habitat speciation and the exploitation of allochthonous carbon by zooplankton. Ecology 87:2800-2812.

Matthews B, Mazumder A, 2007. Distinguishing trophic variation from seasonal and size-based isotopic $\left(\delta^{15} \mathrm{~N}\right)$ variation of zooplankton. Can. J. Fish. Aquat. Sci. 64:74-83.

Matthews B, Mazumder A, 2008. Detecting trophic-level variation in consumer assemblages. Freshwater Biol. 53:19421953.

Moss BD, Hering AJ, Green AA, Becares E, Beklioglu M, Bennion H, Boix D, Brucet S, Carvalho L, Clement B, Davidson T, Declerck S, Dobson M, van Donk E, Dudley B, Feuchtmayr H, Friberg N, Grenouillet G, Hillebrand H, Hobaek A, Irvine K, Jeppesen E, Johnson R, Jones I, Kernan M, Lau- ridsen TL, Manca M, Meerhoff M, Olafsson J, Ormerod S, Papastergiadou E, Penning WE, Ptacnik R, Quintana X, Sandin L, Seferlis M, Simpson G, Triga C, Verdonschot P, Verschoor AM, Weyhenmeyer GA, 2009. Climate change and the future of freshwater biodiversity in Europe: a primer for policy-makers. Freshwater Rev. 2:103-130.

Obertegger U, Manca M, 2011. Response of rotifer functional groups to changing trophic state and crustacean community. J. Limnol. 70:231-238.

Pel R, Hoogveld H, Floris V, 2003. Using the hidden isotopic heterogeneity in phyto- and zooplankton to unmask disparity in trophic carbon transfer. Limnol. Oceanogr. 48:2200-2207.

Perga ME, Gerdeaux D, 2006. Seasonal variability in the $\delta^{13} \mathrm{C}$ and $\delta^{15} \mathrm{~N}$ values of the zooplankton taxa in two alpine lakes. Acta Oecol. 30:69-77.

Persaud AD, Dillon PJ, Molot LA, Hargan KE, 2012. Relationships between body size and trophic position of consumers in temperate freshwater lakes. Aquat. Sci. 74:203-212.

Peters RH, 1983. Size structure of the plankton community along the trophic gradient of Lake Memphremagog. Can. J. Fish. Aquat. Sci. 40:1770-1778.

Peterson BJ, Fry B, 1987. Stable isotopes in ecosystem studies. Annu. Rev. Ecol. Syst. 18:293-320.

Pilotti M, Valerio G, Leoni B, 2013. Data set for hydrodynamic lake model calibration: A deep prealpine case. Water Resour. Res. 49:1-5.

Porter KG, Feig Y, Vetter E, 1983. Morphology, flow regimes, and filtering rates of Daphnia, Ceriodaphnia and Bosmina fed natural bacterioplankton. Oecologia 58:156-163.

Rau GH, Takahashi T, Des Marais DJ, Repeta DJ, Martin JH, 1992. The relationship between $\delta^{13} \mathrm{C}$ of organic matter and $\left[\mathrm{CO}_{2}(\mathrm{aq})\right]$ in ocean surface water: data from a JGOFS site in the northeast Atlantic Ocean and a model. Geochim. Cosmochim. Ac. 56:1413-1419.

Rau GH, Takahashi T, Des Marais DJ, 1989. Latitudinal variations in plankton ${ }^{13} \mathrm{C}$ : implications for $\mathrm{CO}_{2}$ and productivity in past oceans. Nature 341:516-518.

Salmaso N, Buzzi F, Cerasino L, Garibaldi L, Leoni B, Morabito G, Logora M, Simona M, 2014. Influence of atmospheric modes of variability on the limnological characteristics of large lakes south of the Alps: a new emerging paradigm. Hydrobiologia 731:31-48.

Salmaso N, Buzzi F, Garibaldi L, Morabito G, Simona M, 2010. Effects of nutrient availability and temperature on phytoplankton development: a case study from large lakes south of the Alps. Aquat. Sci. 74:555-570.

Rinta P, Bastviken D, van Hardenbroek M, Kankaala P, Leuenberger M, Schilder J, Stötter T, Heiri O, 2015. An inter-regional assessment of concentrations and $\delta^{13} \mathrm{C}$ values of methane and dissolved inorganic carbon in small European lakes. Aquat. Sci. 77:667-680.

Smyntek PM, Maberly SC, Grey J, 2012.Dissolved carbon dioxide concentration controls baseline stable carbon isotope signatures of a lake food web. Limnol. Oceanogr. 57:1292-1302.

Šrf M, Brandl Z, 2012. The rotifer contribution to the diet of Eudiaptomus gracilis (G. O. Sars, 1863) (Copepoda, Calanoida). Crustaceana 85:1421-1429.

Strayer DL, 2010. Alien species in fresh waters: ecological effects, interactions with other stressors, and prospects for the future. Freshwater Biol. 55:152-174. 
Visconti A, Manca M, 2011. Seasonal changes in the $\delta^{13} \mathrm{C}$ and $\delta^{15} \mathrm{~N}$ signatures of the Lago Maggiore pelagic food web. J. Limnol. 70:263-271.

Visconti A, Volta P, Fadda A, Di Guardo A, Manca M, 2014. Seasonality, littoral vs. pelagic carbon sources, and stepwise ${ }^{15} \mathrm{~N}$-enrichment of pelagic food web in a deep subalpine lake: the role of planktivorous fish. Can. J. Fish. Aquat. Sci. 71:436-446.

Vogt RA, Ignoffo TR, Sullivan J, Herndon J, Stillman JH, 2013.
Feeding capabilities and limitations in the nauplii of two pelagic estuarine copepods, Pseudodiaptomus marinus and Oithona davisae. Limnol. Oceanogr. 58:2145-2157.

Wada E, 2009. Stable $\delta^{15} \mathrm{~N}$ and $\delta^{13} \mathrm{C}$ isotope ratios in aquatic ecosystems. Proc. Jpn. Acad. B 85:98-107.

Zohary T, Erez J, Gophen M, Berman-Frank I, Stiller M, 1994. Seasonality of stable carbon isotopes within the pelagic food web of Lake Kinneret. Limnol. Oceanogr. 39: 1030-1043. 